\title{
Family Health Strategy professionals' view on the effects of Hansen's disease training*
}

\author{
A visão de profissionais da Estratégia Saúde da Família sobre \\ os efeitos do treinamento de hanseníase \\ La visión de los profesionales de la Estrategia Salud de la Familia \\ acerca de los efectos del entrenamiento de hanseniasis
}

Ana Lúcia Alves de Souza ${ }^{1}$, Katia Virginia de Oliveira Feliciano' ${ }^{1}$, Marina Ferreira de Medeiros Mendes ${ }^{2}$

\begin{abstract}
* Extracted from the dissertation "Efetividade do treinamento de hanseníase em três municípios do estado de Pernambuco: a visão de profissionais da Estratégia Saúde da Família," Instituto de Medicina Integral Professor Fernando Figueira, 2013

${ }^{1}$ Instituto de Medicina Integral Professor Fernando Figueira, Recife, PE, Brazil.

${ }^{2}$ Fundação Oswaldo Cruz, Centro de Pesquisas Aggeu Magalhães, Recife, PE, Brazil.
\end{abstract}

\section{ABSTRACT}

Objective: Evaluating how professionals of family health teams from three municipalities of Pernambuco perceive and interpret the effects of Hansen's disease training. Methods: A qualitative study using the perspective of Habermas. Six focus groups, totaling 33 nurses and 22 doctors were formed. The guide consisted of: reactions to training, learning, transfer of knowledge and organizational results. Results: There were recurrent positive opinions on instructor performance, course materials, and an alert attitude to the occurrence of cases; the negative points were about lack of practical teaching, a lot of information in a short period of time and little emphasis on basic content. Low perceived self-efficacy and low locus of control, ambiguity, conflict of skills and the lack of support for the learning application. Nurses showed greater dissatisfaction with the organizational support. Conclusion: The low effectiveness of training reveals the need to negotiate structured training from work problematization, considering performance conditions.

\section{DESCRIPTORS}

Leprosy; Patient Care Team; Family Health Strategy; Training; Effectiveness; Health Evaluation. 


\section{INTRODUCTION}

Hansen's disease (HD) is a priority among neglected diseases, a term that refers to endemic transmissible diseases in conditions of poverty, with unacceptable indicators and disability in accessing health services. The training and the integration of control actions in Primary Health Care (PHC, or ABS in Brazil) are essential to strengthen early diagnosis and proper treatment of cases ${ }^{(1)}$. The Family Health Strategy (FHS, or ESF in Brazil) is the central organizing axis of PHC in the Unified National Health System of Brazil (SUS) ${ }^{(2)}$.

In Brazil, investments in training for the control of Hansen's disease (HD, leprosy) deal with the lack of evaluation of these educational activities. The national and international scientific literature on the subject is also limited, as only four studies that evaluated the training to address the disease in PHC were identified. One was held in Mali, which noted the increasing suspicion capacity of leprosy ${ }^{(3)}$. In the others which were conducted in the Northeast and Southeast of the country, most of the FHS professionals acknowledged the usefulness of case detection in training, but insecurity persisted in diagnosing the disease ${ }^{(4-6)}$.

In Pernambuco, a state classified by the Ministry of Health $(\mathrm{MOH})$ as having very high endemicity for general detection of HD (20.0 to 39.9 cases/100,000 inhabitants) and hyperendemic in children under 15 years $(\geq 10$ cases/100,000 inhabitants), training FHS professionals has been prioritized since 2010, without being evaluated. The mission to provide knowledge for improving their short term individual performance ${ }^{(7)}$ makes it essential to assess the effectiveness of $\mathrm{HD}$ training in order to indicate the changes required to contribute to the achievement of better results in educational activities aimed at controlling the disease.

The effectiveness of a program can be measured by the changes that it has on the reality to which it relates. The changes are of two types: impacts refer to actual changes in the reality in which the program operates, for example being measured by the incidence variation of disease rates. Effects relate to the changes produced in the agents that perform actions and institutions to which they are linked ${ }^{(8)}$.

In the evaluations of the effectiveness of training, effects are grouped into two dimensions: (1) individual - related to direct and specific consequences on the training, regarding their opinion about the training (reaction); the acquired skills; the instructor's performance; the pedagogical strategies; the applicability and usefulness of the training and convenience of its dissemination; the obtained learning (learning); the assimilation of knowledge; the opportunities to improve performance and the ability to transmit knowledge; and application of the knowledge and skills acquired in the instructional action (learning transfer) to the work, and (2) organizational - associated with improvement of the organization's capabilities to provide conditions for further development of the actions that the training aims to qualify (organizational results) $^{(7,9-10)}$.

The conditions of the desired effects of training are related to the context, the training characteristics and to the peo- ple trained ${ }^{(7,9-14)}$. In the post-training, organizational support is essential because the context variables have the greatest explicatory power of learning transfer ${ }^{(7,10-11)}$. Training characteristics relate to instructional planning, the execution of training ${ }^{(9-10)}$ and to the trainees, in regards to their commitment at work, their perceived ability to successfully perform a given activity (self-efficacy), the perception that the results come from their own personal practices or from external forces (locus of control) and finally job satisfaction ${ }^{(7,10-12,14)}$.

By allowing organizations to be analyzed as historical and social constructions, the Theory of Communicative Action has brought valuable suggestions for reflection on the effectiveness of training. The action is communicative when participants seek to reconcile the interests and plans of action through discussion, striving for consensus. The argument has an essential role as it mobilizes different views and taking a position necessarily involves the critical evaluation of controversial validity claims that can be accepted or rejected in different contexts, considering the capacities of: (a) developing legitimate actions (correcting or adequacy norms); (b) sharing certainties on facts and occurrences (propositional truth); and (c) establishing effective communication between different subjective perspectives in interaction (expressive authenticity) $)^{(15)}$.

This evaluative study aimed to understand how professionals trained in family health teams in the state of Pernambuco perceive and interpret the individual and organizational effects of HD training. The inclusion of three municipalities with different organizational arrangements and specifics in the work process allowed for verifying variations in the effectiveness of the training, thereby enhancing the ability to more securely demonstrate the essential aspects of the assessed problem and increasing the usefulness of the results.

\section{METHOD}

A qualitative, exploratory study conducted in Olinda, São Lourenço da Mata and Jaboatão dos Guararapes, of the Metropolitan Region of Recife, PE, using theoretical approaches on the effectiveness of training ${ }^{(7,9-10)}$ and the Theory of Communicative Action ${ }^{(15)}$. Municipal selection criteria were: being hyper-endemic ( $\geq 40$ cases $/ 100,000$ inhabitants) or highly endemic for general detection of HD (20.0 to 39.9 cases $/ 100,000$ inhabitants); having cases clustered in time or area; integrating the Coping Program for Neglected Diseases (SANAR); developing HD control activities in primary and secondary levels of care; and relying on FHS doctors and nurses trained in the past two years.

The professionals included were from FHS, trained in a HD clinic by the Department of Health in 2011, with a workload of 16 hours comprising: diagnosis, case classification, treatment, prevention of disabilities and neurological evaluation, reactions and relapses, epidemiological surveillance and program operation. The pedagogical strategies used were lectures and exercises. The training followed the model proposed by the Ministry of Health. With authorization of the municipalities, the professionals were invited by personal contact during a visit to the units where they 
worked, considering the diversity of health districts. Invitations over the phone were exceptions. There were 10 refusals from physicians and two from nurses, in addition to two medical losses.

In April 2013, six focus groups were held, two in each municipality, by professional category: seven doctors and 11 nurses in Olinda; four and 12 in Sao Lourenco da Mata; and 11 and 10 in Jaboatao dos Guararapes, totaling 22 doctors and 33 nurses. The rooms used in the municipalities offered suitable conditions for debate and recording the focus groups; this included the presence of a mediator, an observer and a reporter. Before starting the groups, participants answered an anonymous self-administered questionnaire on vocational training, integration into the FHS and HD training.

The script of the focus groups focused on the components of effectiveness guiding this study: reaction to training, learning, transfer of learning and organizational results $^{(7,9)}$, which were used with flexibility to encourage the expression of ideas and feelings. Each group lasted for an average of 1 hour and 30 minutes. To ensure the anonymity of respondents, municipalities were codified as "M1," "M2" and "M3," and the collective speech as "NG" - for the nurses' group and "DG" - for the doctors' group.

In the analysis, the speech was interpreted within a reference framework that enabled passing on the expressed message and achieving the latent meanings ${ }^{(16)}$. For this, we sought to: a) understand all the speeches from each group and visualize the entirety of the speeches; b) identify the perceptions, the arguments and contradictions present in each group; c) identify the common elements and variations between groups, outlining differences between municipalities and professional categories; d) interpret speeches with 3 researchers questioning the participants about their ideas and feelings, and establishing a dialogue between the subjective dimension and the theoretical framework of the study to understand the implicit meaning. The thematic areas were present in the script.

Because one of the researchers develops management functions at the HD control program at a state level, she did not participate in the field work. Throughout the study, and especially in the analysis of the material, a cooperative vision through a collective process of reflection was encouraged to overcome possible difficulties in addressing everyday problems and questioning the concepts and practices prevailing in the program, in order to be part of the power structure ${ }^{(17)}$.

Informed Consent was obtained from all participants. The project was approved by the Research Ethics Committee of the Prof. Fernando Figueira Institute of Integrated Medicine, under protocol 3363, on January 9, 2013, according to Resolution number 466/2012 of the National Health Council.

\section{RESULTS}

The nurses were all women; $40.6 \%$ had up to 9 years of profession and $54.6 \%$ between 1 and 9 years working in the FHS; $39.4 \%$ between 1 and 4 years of experience in munici- pality of the study; and $54.6 \%$ between 1 and 4 years in the existing team. Among doctors, 59.1\% were men, half had been in the profession for over 40 years, and $59.1 \%$ were between 10 and 19 years of working in the FHS. Half of them had from 5 to 9 years of experience in the municipality, and $45.4 \%$ between 5 and 9 years in the existing team. In the last five years, around $54.5 \%$ of physicians and $66.7 \%$ of nurses had participated in two or three training sessions on aspects of $\mathrm{HD}$ clinical practice (Table 1).

Table 1 - Characteristics of professionals, according to gender, professional experience, insertion in the care model and HD training - Recife, Brazil, 2013.

\begin{tabular}{lcccc}
\hline Variables & $\begin{array}{c}\text { Nurses } \\
(\mathbf{N = 3 3 )}\end{array}$ & $\begin{array}{c}\text { Doctors } \\
(\mathbf{N = 2 2})\end{array}$ \\
\hline $\begin{array}{l}\text { Gender } \\
\text { Female }\end{array}$ & 33 & 100.0 & 9 & 40.9 \\
Male & - & - & 13 & 59.1 \\
Profession time (years) ${ }^{(1)}$ & & & & \\
$1-9$ & 13 & 40.6 & - & - \\
$10-19$ & 9 & 28.2 & 3 & 13.6 \\
$20-39$ & 10 & 31.2 & 8 & 36.4 \\
$40-49$ & - & - & 11 & 50.0 \\
Actuation time in the FHS (years) & & & & \\
$1-4$ & 7 & 21.2 & 3 & 13.6 \\
$5-9$ & 11 & 33.3 & 6 & 27.3 \\
$10-19$ & 12 & 36.4 & 13 & 59.1 \\
$20-29$ & 3 & 9.1 & - & -
\end{tabular}

Actuation time in the FHS of the municipality studied (years)

$\begin{array}{lcccc}1-4 & 13 & 39.4 & 5 & 22.7 \\ 5-9 & 11 & 33.3 & 11 & 50.0 \\ 10-19 & 9 & 27.3 & 6 & 27.3\end{array}$

Time in the existing team (years)

\begin{tabular}{lcccc} 
Less than one & 3 & 9.1 & 1 & 4.5 \\
$1-4$ & 18 & 54.6 & 7 & 31.9 \\
$5-9$ & 7 & 21.2 & 10 & 45.4 \\
$10-19$ & 5 & 15.1 & 4 & 18.2 \\
HD trainings in the last five years & & & & \\
None & - & - & 2 & 9.1 \\
One & 5 & 15.1 & 6 & 27.3 \\
$2-3$ & 22 & 66.7 & 12 & 54.5 \\
$4-5$ & 6 & 18.2 & 2 & 9.1 \\
\hline
\end{tabular}

(1) One nurse did not report her professional time.

\section{REACTIONS TO TRAINING}

With regard to the training program, the professionals showed satisfaction with the quality of the content, but emphasized that little attention was given to clinical classification, differential diagnosis, diagnosis in children, reactions and disability, cited by practitioners as fundamental in exercising qualified clinical practice.

In the content definition, respondents indicated the following as necessary: thinking about the diversity of the staff that is in primary care (M2-DG), considering the different 
competencies/skills of the professional categories and the increasing integration of recent graduates and retired experts into the FHS. One nurse requested the discussion of alternatives for treatment adherence: ideas, options, whether a different proposal was made to PHC and achieved success (M2-NG).

Comments about the large number of trainees and the low working hours for the volume of information were common in the groups, and that the training was only dedicated to theoretical teaching, therefore making it difficult to assimilate. According to interlocutors, the lack of contact with patients compromises the assimilation and learning retention. The simultaneity of theoretical and practical training was a unanimous request to overcome this gap.

\section{I would have absorbed more, you know? Because they taught us about clinical management, the part of the monitoring, evaluation of the patient and then it disconnected, you know? We had the theory and where's the practice? (M1-DG).}

Regarding the teaching strategies adopted in the theoretical learning, professionals tended to evaluate the photos displayed as being distant from reality of the teams. They approved the reading and discussion of clinical cases, recognizing the failure of the isolated use of this resource for learning. In general, the elaborate display of content hindered intelligibility: for the instructor it is the easiest thing, but for us it is not (M1-NG). The instructor's performance provoked praise for his theoretical understanding and experience in the subject, projecting security, and enabling the clarification of doubts.

The training was considered useful, despite the commonplace assertion: I'm not confident to do it (M2-DG), warning about the complexity of HD diagnosis, even for experts. The questions regarding the intention of decentralizing actions, especially by doctors, have emphasized limitations on the transfer of learning to practice.

These trainings are provided with the intention of getting us to do everything at the health center, right? There's no way... (M1-DG).

By addressing the convenience of disseminating the training to other team members, the mention of the Community Health Agents (CHA - FHS team integrant, target-community member, that developed activities of health surveillance at home) was recurrent. For nurses, dentists and nursing staff/technicians should also be trained.

\section{If everyone on the team had this vision, the cases would be detected earlier (M3-NG).}

\section{LEARNING IN TRAINING}

From the statements on the assimilation of knowledge, a strong sense of embarrassment towards the diagnosis of HD due to insufficient learning in neurological assessment and differential diagnosis prevailed. The greatest difficulty of suspicion occurred in paucibacillary cases and in children, and it was perceived as a major barrier to early diagnosis.

The difficulty I see is the medical diagnosis of these lesions, the simpler the lesion, the more compli- cated is the diagnosis. (...) In children, it is even

harder (M1-DG).

The lack of preparation to undertake the clinical classification and degree of disability cases was widely reported to be an obstacle in identifying needs and filling out the notification form. Generally speaking, the professional felt unprepared to monitor the treatment, especially the occurrence of reactions, showing low perceived self-efficacy in assisting an HD patient.

\section{For the classification of clinical forms, I still feel it is quite difficult. (...) The treatment is even more complicated for those who do not have the expertise ... The reactions, right? (M3-DG).}

Despite the perceived limitations in learning, training led to professional opportunities to improve performance, benefitting the suspicion of HD.

\section{(...) before taking this training on HD, I did not know much, but today I am more aware of the problem. When a patient arrives with spots, I already think of the possibility of $H D$, although not confidently (M3-DG).}

Although they would prefer an experienced instructor to take responsibility for training of the $\mathrm{CHA}$, nurses mentioned instructing these team members in pursuing suspected HD cases. However, similar to the doctors, they exposed limitations on their knowledge.

\section{The training that I get I share with other health workers, although they do not have the vision that we have ... (...) even if its mycosis skin, they send the case to us... (M1-NG).}

The limited clinical knowledge of nurses and the devaluation of dermatology education in medical school with a restricted approach to HD were identified as learning difficulty.

\section{THE TRANSFER OF LEARNING AT WORK}

In general, professionals who were part of the teams were covering too many families, experiencing turnover and reducing the workload of doctors. They attributed high importance to working conditions for using the knowledge acquired, reporting the adverse effects of work overload in HD control activities.

\section{How many of the patients that come can I re- ally ask to take their clothes off to examine? How many? I cannot examine all patients as protocol (M2-DG).}

Low frequency and the discontinuity in the occurrence of cases in the area were perceived as major obstacles for maintaining learning. Therefore, with the different presentations of the disease which hindered the diagnosis, and the reactions that complicate treatment, the professionals stated: We do not have enough practice to feel confident (M3$D G)$. Especially those from M1 and M2 were unaware of the HD epidemiological situation and, apart from its origin, did not know how to interpret disease indicators. 
Under the pressure of time and considering the deficiency in performance and the long time spent in neurological evaluation, most doctors are afraid to make clinical decisions on $\mathrm{HD}$, referring suspected cases to referral services: We are not able to establish a definitive diagnosis (M1-DG).

Nurses tended to consider that only cases that were difficult to diagnose had to be referred. As they are subject to institutional accountability for results with a low perceived locus of control, it was common for them to feel helpless in not having technical support on the team to answer questions and share responsibility with cases.

Doctors, in general, have difficulty making the diagnosis, they are always waiting for the dermatologist. (...) Especially those that do not go to training because most of them don't (M1-NG).

According to the statements of some teams, the discussion of cases was routine, in others it was eventual or non-existent, still occurring situations where: You send it to them (doctors) and they send it back to you (M3-NG). In M3, when the team had no doctor or they had not been trained, nurses provided assistance, with specialized support. The professionals in M2 and M3 rarely performed the consultation and notification of aggravation together. There was not enough time to monitor actions. Nurses would also train and supervise CHA, who according to them did not always demonstrate commitment, but they were seen as key in the active search process.

Doctors revealed little involvement in monitoring cases, administrative activities (medication, articulation with reference), information system, active search and surveillance of patient contacts. The lack of teams' internal articulation/ communication was perceived as a major barrier to applying HD learning at work and as an important element of work overload, especially for nurses.

There are places where the nurse has to do it all, giving medicine... And when do we fill out all the paperwork? Family health center nurses are pack mules (M1-DG).

The lack of flexibility in the division of labor and the definition of responsibilities for the team were rarely questioned by doctors. In contrast, conflict and ambiguity of skills was a key issue for most nurses due to dissatisfaction with the inequality of rights and duties between the professional categories. For them, with greater emphasis on M3, the application of learning required looking at how work was divided in the team and thinking about what is the attribution of each worker.

\section{Are we going to leave the patient unattended? A long time we're doing a lot that should not (...) we have to demand that they (the doctors) take over their cases, the clinic. Because all neglected diseases are on the nurses (M3-NG).}

The lack of responsibility for patients and household contacts was another major obstacle to the transfer of knowledge to everyday practice. Professionals pointed out the following as barriers to accountability: (1) the weak perception of the initial manifestations of HD; (2) the reduced perception of personal vulnerability to illness due to the mismatch between devaluation of spots and the perception of HD as a disfiguring disease; (3) fear of discrimination arising from stigma (hidden disease, requesting confidentiality to a professional and being treated in another service); and (4) alcoholism and drug use. Teams tended to frown upon new arriving cases of HD.

\section{Everybody [says] - Darn it! Here comes that hard boring patient, we know we'll have to be looking over his shoulder and the team is already on the back foot (M2-DG).}

The difficulty in patient adherence to diagnostic and therapeutic process requires a redoubled effort, especially from nurses and $\mathrm{CHA}$. The household contacts also resist surveillance actions. The prejudice against HD patients is seen as a hindrance to the application of the learning, and above all professional nurses felt they needed more time to inform and clarify doubts, aiming at co-responsibility. Frustration predominated in the groups caused by the distance between the investment made and the achieved results.

\section{Summoning the communicators is the biggest challenge, we have to insist, but often we miss contacts that were not seen (M2-NG).}

It is work, work, but still you cannot achieve your goal. When you finally complete the treatment of an HD patient, you [say]: - Phew! (M3-NG).

The unsuccessful attempts to ensure adherence have led to worsening of the cases and the persistence of contagion due to the lack of patient and household contacts awareness, thus resulting in feelings of helplessness, devaluation of care and fear of institutional complaints, particularly among nurses.

\section{(...) Girl, do you want to get me in trouble? Do you want me to answer for you? Because it is me who will have to answer for you. I am the one responsible for you (M1-NG).}

\section{Organizational Results}

All the participants expressed dissatisfaction with the lack of support for teamwork, but the nurses gave more detailed reasons for dissatisfaction. They frequently reported that the attitude of the HD coordination was more of accountability and little operational support, hindering the development of actions. There is non-existence of regular technical support able to answer questions in viable time, in addition to great technical insecurity. Only M3 professionals had sensitivity examination kits. In three cities, some teams did not have forms, or had obsolete forms. The information system (filling it out and regular flow) was appointed as the focus of the institution, seen as inattentive to the needs of the patient and teamwork.

\section{The pressure is on the powering/managing of} the system, I think it should be on the patient 
bimself. (...) Many patients go away, do not come back, then we warn/notify them, but it is vague (M1-NG).

The management of medical work in the FHS, prioritizing productivity, makes it difficult to have solid commitments to programmatic actions. Nurses could see the institution as a guarantor of the small participation of doctors in HD control, including the exercise of the clinic. The perceived a lack of support after training which increased the sense of vulnerability at work.

\section{The legal support that we don't have. (...) while everything is going well, this nurse is great, right? When it goes wrong - malpractice of medicine (M3-NG).}

With the HD diagnosis linked to dermatologists, formal connections between services were mentioned a lot. In M1 and M2, the long intervals for scheduling and conducting the consultation caused patient loss. In M3, patient care forwarded on the day for which it was demanded was a facilitator. Generally, they shared the eventual character of counter-referencing, with nurses seeking information from the health service or from the patient.

\section{We send the health worker to go after the patient to know if the diagnosis has been closed, it they have already started treatment (M2-NG).}

Some teams in M3 had the support of physiotherapists of the Family Health Support Center (NASF in Portuguese). Despite the need for monitoring to prevent the consequences and functional limitations, there were no reference flows defined for disability carriers and professionals were uninformed about the services that could meet the rehabilitation need. There was a perception of neglect, especially in cases of patient discharge. There was mention of the lack of psychologists and social workers.
Who is giving support to this patient? No one else, she is there with what's left of her foot, hurt- ing, in need of shoes, none available right? Why? (...) She became a number, she was treated, no- body else will see her, it's over (M2-DG).

To act more safely, professionals requested an expansion of the learning context, continuing the training with an emphasis on practical teaching and grounded in everyday experiences. The understanding of the lack of dialogue and desire to be heard were widespread, although nurses were the ones questioning the predefined character of the management actions the most.

\section{DISCUSSION}

The results showed the recurrence of opinions indicating that small individual and organizational effects of training were resulting in its low effectiveness. In the last five years, a significant proportion of the participants in the groups took part in at least two training sessions that addressed clinical practices of HD, similar in content, workload and emphasis on similar theoretical teaching as evaluated here. Therefore, the results suggest that to achieve the desired ef- fect, it is necessary to consider the articulation of individual and organizational needs ${ }^{(18)}$.

Investments in training can be wasted due to problems in the needs assessment and instructional planning. To define training needs, institutions identify essential individual skills for the intended performance; it is not usual to listen to the needs perceived by professionals ${ }^{(18)}$. Based on the Theory of Communicative Action, one can argue about the strategic nature of rationality commonly used in the needs assessment, which decontextualizes action aimed at pre-established results ${ }^{(15)}$.

The evaluation of responses to training is a promising way to articulate individual and organizational needs ${ }^{(8-9,18)}$. In this study, we have presented positive opinions on the quality of the theoretical content, instructor performance, didactic material and encouraging the adoption of an alert attitude to the occurrence of cases. However, there were negative views about the assimilation and retention of knowledge: lack of practical teaching, a lot of information in a short time, brief explanation of basic content to achieve the required skills and heterogeneity of the trainees. This last element is important in terms of the domain prerequisites, which can make the uninteresting training to be somewhat challenging or very difficult.

Often, learning is evaluated at the end of training ${ }^{(7)}$, although it is known that carrying out assessments for an extended time is important ${ }^{(19)}$. This research examined the perception of training for a medium term, while applying learning to practice, placing greater concreteness on the evaluation of learning objectives in the training.

Direct experience is a key source of information for self-evaluation capabilities. Perceived self-efficacy affects feelings, thinking and behavioral processes that influence individual performance ${ }^{(20)}$, constituting a moderating variable of the relationship between acquisition and transfer of learning from training ${ }^{(9,13)}$.

In this study, despite the recognition of the instrumental value of the training element which is correlated with learning transfer ${ }^{(7)}$, both occupational categories showed great insecurity to assume responsibility for presumptive diagnosis, particularly in paucibacillary cases and in children. However, the epidemiological profile of HD indicates the need to prioritize those under 15 years of age, who may be the contacts of cases not yet identified by health services.

Lack of confidence in diagnosing and starting treatment has been proven in evaluating the effectiveness of HD training carried out in the country ${ }^{(4-6)}$, as well as in an investigation about the work process of HD within the $\mathrm{FHS}^{(21)}$.

In this research, statements indicated a desire to continue the training of a perspective that approached permanent health education, which has a pedagogical assumption to link learning to significant elements for those involved with the training processes structured from the problematization of work ${ }^{(2)}$.

Studies on the effectiveness of training conducted in other contexts show the importance of support during transfer of learning, encouraging reflection on their own performance and the exchange of information on 
experiences at work ${ }^{(22-23)}$. The possibility of expansion of knowledge is greater when there is prior knowledge on the topic ${ }^{(24)}$. The absence of HD content in the curricula of these professionals is worth noting ${ }^{(25)}$.

Practical application of HD knowledge is usually resented by internal disarticulation of the teams and instrumental communication between professionals, which sometimes leads to tension in interpersonal relationships. The fragmentation of work organization, knowledge and interaction among members, which features teams with low integration $^{(26)}$, is an important element of work overload, especially for nurses, as verified in another study ${ }^{(21)}$.

Communication is the vehicle that enables the articulation of actions and interaction among the team members. For communicative practices to be an organizing principle of the work, it is necessary to seek understanding and mutual recognition. Within the framework of communicative action, understanding is crucial to the coordination of actions aiming for the result that the work needs to pursue and achieve ${ }^{(15)}$. The desired individual performance by training is linked to the performance of the team with regard to internal communication, problem solving and decision making ${ }^{(13)}$.

The contexts where the agreements with the institutions seemed to distance doctors from programmatic actions were when the planning of HD training, competencies and responsibilities differ, and those which are similar to doctors and nurses were not discussed. This favors ambiguity in daily work, with negative effects on the individual and collective performances. The professional delegation of responsibility is essential in bringing them closer to the results of their work, and commitment to the patients ${ }^{(26)}$.

The challenges experienced by these professionals to increase case detection and treatment adherence bring to light an important point: training did not stimulate reflection on the repercussions of HD perception in the application of learning. The valuation of only the informative dimension of communication hindered the understanding of the needs in local contexts and minimized the importance of negotiating individual therapeutic projects ${ }^{(27)}$.

In coping with a disease that causes prejudice and discrimination, it can be argued from the perspective of the Theory of Communicative Action that language is used as a means for transmitting information, inducing a default behavior without giving room for patients and contacts' arguments ${ }^{(15)}$. The required responsibility with the results of actions and a commitment to resolution was reiterated in the groups as a fundamental element from learning application; it implies dialogue and understanding of the different meanings that illness and health practices have for the subjects ${ }^{(28)}$.

The disregard of the conflict between values and interests guided by the decisions of professionals, patients and contacts certainly favored the perception of exhausting resources used in the attempt at persuading those to act in providing guidance. Especially among nurses, there was the impression of ascendant external, uncontrollable forces that diminished positive results.
It is known that the ability to control performance influences the motivation for learning transfer ${ }^{(12-13)}$. Motivational variables affecting effort and persistence in engaging in activities are a stronger predictor with individual success than the cognitive abilities and the demographic characteristics of trained staff ${ }^{(11)}$. However, the support to transfer is the main predictor of individual performance resulting from training ${ }^{(7,9-10,14)}$.

In being subject to institutional pressures, with a higher perception of low locus of control, and feeling vulnerable by lack of technical support and the blurring of powers and responsibilities, thus revealing nurses to be more dissatisfied with the organizational support.

By investing in training, institutions tend to overestimate the ability of individuals to bring about changes in the team and the organization. Knowing and being willing are not sufficient conditions for implementing work performances learned in training ${ }^{(14)}$. The will of the members is necessary but insufficient for cooperative teamwork, while the institution provides intra-team cooperation ${ }^{(10)}$. The organizational support is essential to ensure the necessary conditions to increase the autonomy of the team as a whole, seeking the sustainability of the changes at work. Infrastructure, communication, control, conflict and trust are important determinants of the perception of an organizational environment ${ }^{(7,9-11,14)}$.

The views of professionals on relationships with the managerial levels indicate that there is practically no room for understanding the experiences, limiting questioning to the needs related to training and working conditions for learning transfer. In the conceiving of the Theory of Communicative Action $^{(15)}$, in these contexts, management obscures the daily conflict of interest that makes it necessary to practice discussion. However, institutions must learn to deal with the different interest groups, seeking greater flexibility in dealing with issues related to training processes. Negotiations are essential to improve performance in the development of HD control actions.

\section{CONCLUSION}

The view of trained staff on the low efficiency of $\mathrm{HD}$ clinical training shows significant barriers for the early detection and timely treatment of cases. The performance qualification implies negotiations to: 1 ) define the competencies and responsibilities of each professional category; 2) structure the training from the problematization of work, based on theory-practice integration, considering the individual's, the team's and the organization's performance conditions; 3) introduce health communication about content, highlighting its dialogical dimension without overlooking informative communication; 4) empower other team members, paying attention to the unique role of the CHA; 5) support the municipality in the systematic supervision focused on providing technical, psychosocial, material and informational support to the teams; and 6) monitor the actions also based on indicators of training effects.

The recommendations above, resulting from the combination of different and complementary views that 
allowed to shed light on the strengths and the weaknesses of HD training aim to contribute to the formulation of educational and organizational strategies that enhance disease control.

\section{RESUMO}

Objetivo: Avaliar como os profissionais das equipes de saúde da família de três municípios de Pernambuco percebem e interpretam os efeitos do treinamento de hanseníase. Método: Estudo qualitativo que utiliza perspectiva habermasiana. Formalizaram-se seis grupos focais, perfazendo 33 enfermeiras e 22 médicos. Constaram do roteiro: reações ao treinamento, aprendizagem, transferência de aprendizagem e resultados organizacionais. Resultados: Foram recorrentes as opiniões positivas sobre o desempenho do instrutor, o material didático, a atitude de alerta à ocorrência de casos, negativas sobre falta de ensino prático, muita informação em curto tempo e pouca ênfase em conteúdos básicos. Perceberam baixa autoeficácia e baixo locus de controle, ambiguidade, conflito de competências e a falta de suporte à aplicação do aprendido. As enfermeiras mostraram maior insatisfação com o suporte organizacional. Conclusão: A baixa efetividade do treinamento revela a necessidade de negociar a capacitação a partir da problematização do trabalho, considerando as condições para o desempenho.

\section{DESCRITORES}

Hanseníase; Equipe de Assistência ao Paciente; Estratégia Saúde da Família; Capacitação; Efetividade; Avaliação em Saúde.

\section{RESUMEN}

Objetivo: Evaluar cómo los profesionales de los equipos de salud de la familia de tres municipios de Pernambuco perciben e interpretan los efectos del entrenamiento de hanseniasis. Método: Estudio cualitativo que utiliza la perspectiva habermasiana. Se formalizaron seis grupos focales, totalizando 33 enfermeras y 22 médicos. Figuraron en el guión: reacciones al entrenamiento, aprendizaje, transferencia de aprendizaje y resultados organizativos. Resultados: Fueron recurrentes las opiniones positivas acerca del desempeño del instructor, el material didáctico, la actitud de alerta a la ocurrencia de casos, negativas sobre falta de enseñanza práctica, mucha información a corto plazo y poca énfasis a los contenidos básicos. Notaron baja autoeficacia y bajo locus de control, ambigüedad, conflicto de competencias y la falta de soporte a la aplicación de lo aprendido. Las enfermeras mostraron mayor insatisfacción con el soporte organizativo. Conclusión: La baja efectividad del entrenamiento revela la necesidad de negociar la capacitación desde la problematización del trabajo, considerando las condiciones para el desempeño.

\section{DESCRIPTORES}

Lepra; Grupo de Atención al Paciente; Estrategia de Salud Familiar; Capacitación; Efectividad; Evaluación en Salud.

\section{REFERENCES}

1. Brasil. Ministério da Saúde; Secretaria de Políticas de Saúde, Departamento de Atenção Básica. Guia para o controle da hanseníase [Internet]. Brasília; 2002 [citado 2014 jul. 03]. Disponível em: http://bvsms.saude.gov.br/bvs/publicacoes/guia_de_hanseniase.pdf

2. Brasil. Ministério da Saúde. PNB - Política Nacional de Atenção Básica [Internet]. 4ª ed. Brasília; 2012 [citado 2014 jul. 03]. Disponível em: http://189.28.128.100/dab/docs/publicacoes/geral/pnab.pdf

3. Faye O, Hay RJ, Ryan TJ, Keita S, Traore AK, Mahe A. A public health approach for leprosy detection based on a very short term-training of primary health care workers in basic dermatology. Lepr Rev. 2007;78(1):11-6.

4. Moreira TMA, Pimentel MIF, Braga CAV, Valle CLP, Xavier AGM. Hanseníase na atenção básica de saúde: efetividade dos treinamentos para os profissionais de saúde no Estado do Rio de Janeiro, Brasil. Hansen Int. 2002;27(2):70-6.

5. Moreno CMC, Enders BC, Simpson CA. Avaliação das capacitações de hanseníase: opinião de médicos e enfermeiros das equipes de saúde da família. Rev Bras Enferm 2008;61(n.esp):671-5.

6. Lima, MSM, Pomini ACM, Hinders D, Soares MPB, Mello MGS. Capacitação técnica versus comprometimento profissional: o real impacto no controle da hanseníase. Cad Saúde Colet. 2008;16(2):293-306.

7. Scorsolini-Comin F, Inocente DF, Miura IK. Avaliação de programas de treinamento, desenvolvimento e educação no contexto organizacional: modelos e perspectivas. Rev Psicol Organ Trab [Internet]. 2011 [citado 2014 out. 15];11(1):37-53. Disponível em: https://periodicos. ufsc.br/index.php/rpot/article/view/22245/20171

8. Draibe SM. Avaliação de implementação: esboço de uma metodologia de trabalho em políticas públicas. In: Barreira MCRN, Carvalho MCB, editores. Tendências e perspectivas na avaliação de políticas e programas sociais. São Paulo: IEE/PUC-SP; 2001. p.13-42.

9. Abbad G, Pilati R, Pantoja MJ. Avaliação de treinamento: análise da literatura e agenda de pesquisa. Rev Adm USP. 2003;38(3):205-18.

10. Zerbini T, Abbad G. Transferência de treinamento e impacto do treinamento no trabalho: análise crítica da literatura. Rev Psicol Organ Trab [Internet]. 2010 [citado 2014 out. 15];10(2):97-111. Disponível em: https://periodicos.ufsc.br/index.php/rpot/article/view/22212

11. Balarin CS, Zerbini T, Martins LB. A relação entre suporte à aprendizagem e impacto de treinamento no trabalho. REAd Rev Eletr Adm (Porto Alegre) [Internet]. 2014 [citado 2015 mar. 06];78(2):341-70. Disponível em: http://www.scielo.br/pdf/read/v20n2/1413-2311-read-20-02-0341.pdf

12. Meneses PPM, Abbad G. Locus de controle: validação de uma escala em situação de treinamento. Estud Psicol. 2004;9(3):441-50.

13. Brandão HP, Borges-Andrade JE, Puente-Palacios KJ, Laros JA. Relationships between learning, context and competency: a multilevel study. BAR Braz Adm Rev [Internet]. 2012 [cited 2015 Mar o5];9(1):1-22. Available from: http://www.scielo.br/pdf/bar/v9n1/a02v9n1.pdf 
14. Santos Filho GM, Mourão L. A relação entre comprometimento organizacional e impacto do treinamento no trabalho. Rev Psicol Organ Trab [Internet]. 2011 [cited 2014 out. 22];11(1):66-74. Disponível em: https://periodicos.ufsc.br/index.php/rpot/article/view/22248

15. Habermas J. Teoria de la acción comunicativa. $2^{\text {a }}$ ed. Madrid: Taurus; 1988. Tomo 1.

16. Worthen BR, Sanders JR, Fitzpatrick JL. Avaliação de programas: concepções e práticas. São Paulo: Gente; 2004. Avaliações centradas nos participantes; p. 223-43.

17. Minayo MCS. O desafio do conhecimento: pesquisa qualitativa em saúde. 13ª ed. Rio de Janeiro: ABRASCO; 2013. Técnicas de análise de material qualitativo; p. 303-60.

18. Zerbini T, Meneses PPM. Levantamento de necessidades de treinamento: reflexões atuais. Análise (Porto Alegre) [Internet]. 2009 [citado 2014 out. 22];20(2):50-64. Disponível em: http://revistaseletronicas.pucrs.br/ojs/index.php/face/article/view/2644/5079

19. Otrentei E, Mira VL, Bucchi SM, Borges-Andrade JE. Evaluation of formal educational processes for healthcare professional. Invest Educ Enferm. 2014;32(2):103-11.

20. Tsang SKM, Hui EKP, Law BCM. Self-Efficacy as a positive youth development construct: a conceptual review. Sci World J [Internet]. 2012 [cited 2015 Mar 17]. Available from: http://www.ncbi.nlm.nih.gov/pmc/articles/PMC3351108/

21. Lanza FM, Lana FCF. O processo de trabalho em hanseníase: tecnologias e atuação da equipe de saúde da família. Texto Contexto Enferm. $2011 ; 20$ (n.esp):238-46

22. Ridde V, Fournier P, Banza B, Tourigny C, Ouédraogo D. Programme evaluation training for health professionals in francophone Africa: process, competence acquisition and use. Hum Resour Health [Internet]. 2009 [cited 2014 July 17]; 7:3. Available from: http://www.ncbi. nlm.nih.gov/pmc/articles/PMC2647897/

23. Roos M, Kadmon M, Kirschfink M, Koch E, Jünger J, Strittmatter-Haubold V, et al. Developing medical educators - a mixed method evaluation of a teaching education program. Med Educ Online [Internet]. 2014 [cited 2014 Sept 17];19:23868. Available from: http://www. ncbi.nlm.nih.gov/pmc/articles/PMC3969510/

24. Mira VL, Peduzzi M, Melleiro MM, Tronchin DMR, Prado MFF, Santos PT, et al. Analysis of the learning evaluation process of nursing staff factions. Rev Esc Enferm USP [Internet]. 2011 [cited 2014 Oct 17];45(n.spe):1574-81. Available from: http://www.scielo.br/pdf/reeusp/ v45nspe/en_v45nspea06.pdf

25. Alves CRP, Melo EM, Ribeiro MMF, Araújo MG. Teaching of leprosy: current challenges. An Bras Dermatol. 2014;89(3):454-9.

26. Ladhani1 Z, Stevens FJ, Scherpbier AJ. Does community health care require different competencies from physicians and nurses? BMC Med Educ [Internet]. 2014 [cited 2014 Sept 12];14:1. Available from: http://www.ncbi.nlm.nih.gov/pmc/articles/PMC3893590/

27. Feliciano KVO. Aspectos da comunicação nas práticas avaliativas na Estratégia Saúde da Família. Rev Bras Saúde Matern Infant. 2010;10(1 Supl):219-27.

28. Peters RMH, Dadun LM, Miranda-Galarza B, van Brakel WH, Zweekhorst MB, Damayanti R, et al. The meaning of leprosy and everyday experiences: en exploration in Cirebon, Indonesia. J Trop Med [Internet]. 2013 [cited 2014 Aug 15]:507034. Available from: http://www. ncbi.nlm.nih.gov/pmc/articles/PMC3615632/ 